\title{
Sosialisasi Kewirausahaan dan Pendidikan Anak; Antara Bisnis On Line dan Mengasuh di Era Digital
}

\author{
Nuryetty Zain \\ Universitas Negeri Jakarta, Indonesia, nuryetty_zain@unj.ac.id \\ Susan Febriantina \\ Universitas Negeri Jakarta, Indonesia, susanfebriantina@ unj.ac.id \\ Marsofiyati \\ Universitas Negeri Jakarta, Indonesia, ophie.three@gmail.com
}

\begin{abstract}
This activity aims to empower tech-savvy citizens to increase family incomes through networked businesses. Besides, this program also empowered people to technically literate children's education in the digital age. Both of the activities are integrated in one program. The activity method used in this program is expected to give ease to the participants of the activity. In this activity, the method used is explanation method, sharing, questioning, case study, discussion and online shop applicationpractice. In the explanatory method, each instructor delivers the related material and planned to make a power point slide and brief activitiesmodule to be distributed to the participants of the activity. The results achieved in this activity are1) the advantage of the activity was very useful for the participants; 2) the participants were also enthusiastic in giving responses during the activity; 3) this activity was supported by some nongovernmental organizations such asthe forum of children' friendly city at Depok(FOKLA Depok) and Tunas Ilmu Foundation. Finally, we can conclude this activity was very useful for the people around.
\end{abstract}

Key Words: enterpreuneurship, tech-savvy citizens, online shop, children's education

\section{PENDAHULUAN}

\section{Analisi Situasi}

Bagi masyarakat yang hidup dizaman serba digital, istilah teknologi internet bukan menjadi sesuatu yang baru. Peningkatan kualitas hidup semakin menuntut manusia untuk melakukan berbagai aktifitas dengan mengoptimalkan semua sumber daya yang dimilikinya, termasuk perkembangan teknologi dan informasi.

Pesatnya potensi pemanfaatan teknologi internet melalui bisnis daring atau online shop menjadi peluang

Available at

http://journal.unj.ac.id/unj/index.php/jpm 
bagiberkembangnya upaya pemberdayaan dan peningkatan ekonomi kerakyatan berbasis teknologi. Hal ini terutama dapat dilakukan di wilayah perkotaan besar, atau pinggiran wilayah kota besar dengan tingkat penggunaan internet yang tinggi. Sosialisasi dan pelatihan terkait pemberdayaan teknologi internet melalui bisnis daring atau online shopmenjadi hal yang sangat penting dilakukan, termasuk didalamnya sosialisasi dan edukasi kepada para ibu rumah tangga dalam meningkatkan penghasilan rumah tangga agar kesejahteraan keluarga meningkat.

Melakukan bisnis online shop di rumah dapat disesuaikan dengan kemampuan dan keahlian ibu rumah tangga tersebut. Berikut terdapat beberapa contoh peluang usaha yang dapat dilakukan oleh ibu rumah tangga seperti penulis freelance, bisnis tanaman, parcel, catering, membuka tempat les, jahit, kerajinan tangan, reseller barang serta kegiatan bisnis lainnya.eluang usaha berbasis teknologi internet diatas dapat mendatangkan pendapatan bagi para ibu rumah tangga. Terlebih bisnis melalui daring atau online shop tidak memerlukan modal uang yang banyak, cukup bermodalkan handphone atau gadget dengan berbagai aplikasi gambar-gambar yang dapat di lakukan di berbagai media sosial. Penjual dan pembeli tidak perlu saling bertatap muka untuk bertransaksi. Bahkan, bagi yang berjauhan pun dapat melakukannya hanya dalam hitungan detik, tanpa harus lelah memilih, hanya dengan menggeserkan jari-jari tangan, barang yang disukai dapat dibeli dengan mudah.

Fenomena pesatnya teknologi internet tentunya juga membawa dampak yang negatif khususnya terhadap perkembangan pendidikan anak-anak dan remaja. Teknologi internet yang dengan mudah dapat diakses oleh siapapun dan dari manapun memudahkan anak-anak dan remaja dalam menerima dan mencari informasi dari berbagai sumber dengan cepat dan tanpa batas. Sehingga perkembangan teknologi internet ini bagaikan dua sisi mata uang, yakni sisi positif dan sisi negatif. Anak-anak dapat mengakses dengan mudah gambar-gambar atau video-video yang belum layak mereka tonton, belum lagi maraknya kekerasan 
di media internet yang dengan mudah dapat diakses semua kalangan, termasuk anak-anak dan remaja menambah daftar kekhawatiran kita akan sisi negatif berkembangnya teknologi saat ini.

Peran orang tua, terutama ibu menjadi sangat penting dalam membentengi anak-anak akan dampak negatif dari penggunaan teknologi internet. Sebagai orang tua pembatasan dan pengetahuan tentang penggunaan teknologi informasi dan komunikasi dinilai sangat penting dilakukan sehingga anak-anak terlindungi dari pengaruh negatif informasi yang tanpa batas dan tanpa mengenal usia.

Dalam Rencana Pembangunan Jangka Menengah Daerah (RPJMD) kota Depok tahun 2016, menjadikan 'Depok Cyber City' merupakan salah satu program unggulan yang akan diwujudkan oleh pemerintah kota (pemkot) Depok dalam waktu dekat ini. Depok Cyber City merupakan program pemerintah kota dalam bidang Teknologi Informasi (TI) yang bertujuan membantu masyarakat untuk mengenal dan menggunakan fasilitas internet secara gratis di lingkungan kota Depok. Menuju Depok Cyber City ini, pemerintah kota Depok berencana membangun sejumlah fasilitas yang bisa mendukung terwujudnya impian ini. Antara lain dalam waktu dekat Pemkot Depok akan merealisasikan pembangunan gedung cyber. Secara bertahap kedepannya pemkot Depok juga berencana mangadakan wi-fi di tiap kelurahan.

Kebijakan di atas tentunya menjadi sebuah peluang dan mungkin juga ancaman bagi masyarakat kota Depok. Menjadi peluang jika masyarakat mampu menggunakannya dengan sebaik-baiknya untuk meningkatkan kehidupan yang lebih baik, dan menjadi ancaman jika peluang tersebut malah menjadi bumerang bagi perkembangan anak-anak dan remaja di wilayah kota Depok.

\section{Perumusan Masalah}

Berdasarkan uraian diatas, dapat diidentifikasi berbagai masalah sebagai berikut; 1) Bagaimana memberdayakan masyarakat khususnya ibu-ibu rumah tangga di daerah pinggiran ibu kota dalam meningkatkan pendapatan keluarga melalui bisnis daring? 2) Bagaimana memberdayakan masyarakat khususnya ibu-ibu rumah tangga di 
daerah pinggiran ibu kota dalam mendidik anak di era digital? dan 3) Bagaimana memberdayakan masyarakat khususnya ibu-ibu rumah tangga di daerah pinggiran ibu kota dalam meningkatkan pendapatan keluarga melalui bisnis daring dan mendidik anak yang tepat di era digital?

Berdasarkan hal diatas penulis sangat tertarik untuk mengkaji terkait pemberdayaan pemanfaatan teknologi internet dalam rangka meningkatkan pendapatan keluarga melalui online shop serta upaya mendidik anak di era digital. Dalam hal ini penulis memberikan pengabdian kepada masyarakat berupa Sosialisasi Kewirausahaan dan Pendidikan Anak; Antara Bisnis On Line dan Mengasuh di Era Digital

\section{Tujuan dan Manfaat}

Kegiatan ini bertujuan untuk; 1) Memberdayakan masyarakat melek teknologi terhadap peningkatan pendapatan keluarga melalui bisnis daring; 2) Memberdayakan masyarakat melek teknologi terhadap pendidikan anak yang tepat di era digital; dan 3) Memberdayakan masyarakat melek teknologi terhadap peningkatan pendapatan keluarga melalui bisnis daring dan pendidikan anak yang tepat di era digital.Adapun manfaat dari kegiatan ini adalah; 1) Peningkatan pemberdayaan masyarakat melek internet terhadap kebermanfaatan teknologi internet untuk menambah pendapatan keluarga;2) Peningkatan pemahaman masyarakat melek internet terhadap cara mendidika anak yang benar di era digital; dan 3) Peningkatan pemberdayaan masyarakat melek internet terhadap kebermanfaatan teknologi internet untuk menambah pendapatan keluarga dan pendidikan anak yang tepat di era digital.

\section{KAJIANTEORITIK}

Teknologi internet terbukti berhasil cepat membantu upaya-upaya mengurangi kemiskinan atau meningkatkan penghasilan baik pada skala makro maupun skala mikro di Negara-negara yang sedang berkembang, seperti Peru, Cina, Zimbabwe, dan India.

Pengalaman-pengalamandan pelajaran yang diperoleh dari usaha serupa ditempat lain menunjukkan bahwa teknologi internet paling efektif 
bila digunakan sebagai penambah penghasilan baik bagi pemerintah maupun rumah tangga. Teknologi internet ternyata berdampak pada strategi kehidupan para pengusaha kecil (termasuk rumah tangga) dan pengusaha local dalam memperoleh modal dari kategori-kategori berikut:a) Modal dasar: kesempatan mengakses kebijakan-kebijakan pemerintah; b) Modal keuangan (Financial Capital): komunikasi dengan pihak-pihak pemberi dana misalnya kredit mikro (microcredit); c) Modal sumber daya manusia (Human Capital): penambahan pengetahuan melalui proses-proses dan pembelajaran jarak jauh yang diperlukan untuk sertifikasi/izin usaha; d) Modal sosial (Social Capital): menjalin hubungan keluar komunitasnya sendiri.

Teknologi internet menjadi daya tarik tersendiri bagi para pengusaha wanita (yang di banyak Negara berkembang merupakan pelaku pasar terbanyak di bidang usaha kecil dan menengah), karena dapat menghemat waktu dan uang sambil meraih pelanggan baru di pasar domestik dan internasional. Kisah-kisah sukses dalam usaha business-to-consumer (B2C) atau e-retailing diperoleh dari semua wilayah Negara berkembang, yang membuktikan betapa para wanita telah memanfaatkan Internet untuk memperluas basis pelanggan mereka di pasaran luar, mampu menggabungkan tugas-tugas rumah tangga dengan usaha dagang yang dilakukan secara daring.

Berikut beberapa manfaat dari bisnis daring atau online yakni 1) Tidak memerlukan banyak tempat, artinya kita hanya perlu sebuah meja dengan kursi dan mempunyai komputer/laptop bahkan dengan handpone pun transaksi juga bisa dapat berjalan dengan lancar; 2) Tidak perlu memerlukan banyak modalartinya bisnis daring tidak perlu memiliki banyak modal bahkan tanpa modal sekalipun masih bisa berjalan yakni dengan cara memanfaatkan media-media sosial gratis seperti facebook,twitter, $g+, \quad$ whatsap, instagramdan juga bisa memanfaatkan aplikasi lain yang ada; 3) Promosi mudah dilakukan artinya dengan hanya memanfaatkan media sosial pun bisnis daring dapat di kenal banyak oleh seluruh pengguna internet di dunia. 
Manfaat internet semakin sangat terasa bagi para pemakainya yang tidak bisa lepas dari dunia internet mislanya para internet marketing, narablog, blogger, dan juga sekarang toko online semakin mempunyai tempat di mata para konsumen yang sedang mencari barang tertentu. Konsumen tidak perlu repot lagi untuk memperoleh suatu barang. Bisa sekedar mencari tambahan informasi seputar barang yang diinginkan atau bahkan sekaligus memesan, membayar dan menyelesaikan semua transaksi, dan selanjutnya tinggal menunggu barang datang diantar sesuai alamat yang kita minta.Emil Durkheim mendefinisikan pendidikan sebagai pengaruh yang dilaksanakan oleh orang dewasa atas generasi yang belum matang untuk penghidupan sosial. Sementara Dictionary of Education menyatakan bahwa pendidikan merupakan proses dimana seseorang mengembangkan kemampuan, sikap, dan bentuk-bentuk perilaku lainnya di dalam masyarakat dimana yang bersangkutan hidup. Dengan demikian dapat dikatakan bahwa pendidikan adalah proses timbal balik dari tiap pribadi manusia dalam penyesuaian dirinya dengan lingkungan hidupnya.

Pendidikan yang paling utama dan pertama adalah pendidikan di keluarga, selanjutnya di lembaga pendidikan, dan masyarakat. Ketiganya harus saling mendukung dan memberi kontribusi, sehingga proses timbal balik dari setiap manusia dengan lingkungannya berjalan sebagaimana semestinya. Tilaar mengemukakan bahwa dunia pendidikan secara umum saat ini masih dihadapkan pada kerusakan yang tengah dialami bangsa Indonesia, yaitu permasalahan "krisis multidimensi". Artinya, krisis yang tengah melanda bangsa ini tidak hanya dalam bidang financial moneter (keuangan) semata, melainkan juga adanya pengelolaan yang lemah (weak governance) dalam urusan pemerintahan serta kekuasaan, sehingga semakin merambah meliputi semua segi kehidupan bangsa.

Demikian juga dengan teknologi yang semakin maju dan perkembangan dunia digital yang semakin pesat ternyata memberikan tantangan baru bagi para orang tua dalam mendidik anak-anaknya. Santrockmengatakan bahwa mendidik anak di era digital ini 
terbilang berat. Sebagai orang tua, selain harus bisa mengikuti perkembangan teknologi, kita juga perlu memiliki strategi baru dalam mengasuh anak. Sebagai orang tua, kita perlu mengetahui empat tantangan besar yang harus kita hadapi saat membesarkan anak di era digital yang semakin mengglobal ini. Keempat tantangan tersebut adalah:1)Anak-anak tidak belajar melalui interaksi tatap muka langsung; 2) Kemampuan membaca anak-anak bisa menurun; 3) Anakanakmakin jarang bermain di alam; 4) Anak-anak butuh lebih banyak waktu untuk didampingi.

Selain itu terdapat beberapa hal yang harus diperhatikan orang tua dalam mendidik anak di era digital yakni; 1) belajar dan mengenal TIK (Teknologi Informasi dan Komunikasi); 2) sebagai pendidik orang tua harus mutlak mengetahui dan tahu bagaimana menggunakan media sosial sebagai hal yang sering dieksplorasi oleh anak. Setidaknya orang tua dapat membatasi dan mengawasi gerak anak dalam menggunakan sosial media; 3) menyaring dan menyeleksi kontennya serta melakukan pendampingan. Orang tua diupayakan melakukan pendampingan selama anak mengeksplorasi media sosial, setidaknya bisa memilih konten atau aplikasi yang cocok untuk anak agar terhindar dari informasi yang negatif; dan 4) mengendalikan waktu akses dan Mengajak anak bermain dan berinteraksi tanpa alat komunikasi. Kelemahan orang tua dalam hal ini terlalu membebaskan anak dalam mengakses media sosial, orang tua harus bisa menyingkirkan gadget ketika berkumpul dengan keluarga agar komunikasi yang terjalin menjadi lebih optimal; 5) mempelajari apa yang bermanfaat dari teknologi, mulai dari kita sebagai orang tua. Orang tua harus menjadi role model bagi anak karena anak banyak mengikuti apa yang dilakukan oleh orang tua.

Sementara itu pakar Psikologi Anak, Elli Risman mengatakan bahwaTerdapat beberapa media yang harus di awasi oleh orang tua diantaranyaadalah internet, games, film/sinetron dan play station, komik, dan iklan.KArenanya, untuk menjadikan anak tanguh di era digital, yang harus dilakukan orang tua adalah 
1) menghadirkan Tuhan di dalam diri anak; 2) memperbaiki pola pegasuhan; 3) memberikan anak pengakuan, penerimaan; 3) membimbing anak agar bisa mandiri dan bertanggung jawab pada Tuhan, diri sendiri, keluarga dan masyarakat; dan 5) memberikan fasilitas kepada anak dengan landasan dan persayratan agama yang jelas.

\section{MATERI DAN METODE}

\section{Kerangka Pemecahan Masalah}

Berdasarkan diskusi yang dilakukan oleh tim pengabdian masyarakat pada program kegiatan ini, masyarakat khususnya ibu rumah tangga di wilayah kota Depok memerlukan program kegiatan ini dengan pertimbangan; a) kurangnya kesadaran masyarakat terhadap pemanfaatan teknologi internet dalam rangka meningkatkan pendapatan keluarga;b) kurangnya pemahaman masyarakat akan upaya mendidik anak di era digital;c) kurangnya pemahaman masyarakat terhadap pemanfaatan teknologi internet dalam meningkatkan pendapatan keluarga dan upaya mendidik anak di era digital.

\section{Realisasi Pemecahan Masalah}

Available at

http://journal.unj.ac.id/unj/index.php/jpm
Pelaksanaan program kegiatan ini adalah pada tanggal 4 Oktober 2016 2016 yang bertempat di Kota Depok (Depok Cyber City). Kegiatan inidilaksanakan pada pukul 09.00 sampai dengan 13.00 WIB.Tim pengabdian masyarakatmenyusun evaluasi terkait dengan pemahaman peserta terhadap materi kegiatan, pelaksanaan kegiatan secara keseluruhan untuk menampung kemungkinan dibutuhkannya kegiatan dengan materi lain dan tertibnya pelaksanaan program kegiatan ini.

\section{Khalayak Sasaran}

Peserta yang hadir dalam kegiatan ini adalah ibu-ibu muda PKK dan karang taruna di Kelurahan Beji Timur Kota Depok yang memiliki smartphone atau gadget. Berdasarkan observasi pra pengabdian, peneliti menyimpulkan bahwa kelurahan Beji Timur Kota Depok merupakan salah satu kelurahan yang paling dekat ke pusat kota Depok sebagai Cyber City dengan akses internet dan Wifi sangat cepat. Hampir kebanyakan masyarakat kelurahan Beji Timur khususnya ibu rumah tangga memiliki smartphone yang digunakan hanya untuk keperluan komunikasi 
semata atau bahkan untuk mengimbangi gaya hidup modern. Kegiatan ini terkait dengan instansi seperti Universitas Negeri Jakarta yang membiayai kegiatan Pengabdian kepada Masyarakat yang dilaksanakan oleh dosen-dosen sebagai sebuah kewajiban atas Tridharma Perguruan Tinggi serta pemerintah setempat mulai dari Kelurahan sampat tingkat Rukun Warga yang memberikan perizinan untuk kegiatan ini.

\section{Metode Kegiatan}

Metode kegiatan yang digunakan pada program kegiatan ini diharapkan dapat memberikan kemudahan kepada peserta kegiatan. Dalam kegiatan ini, metode yang digunakan adalah metode penjelasan, sharing, tanya jawab, studi kasus, diskusi dan praktek membuat aplikasi online shop. Pada metode penjelasan, setiap instruktur menyampaikan materi terkait dan setiap instruktur direncanakan akan membuat power point slide dan modul ringkas kegiatan yang akan dibagikan kepada peserta kegiatan. Adapun alat bantu kegiatan seperti LCD proyektor juga direncakan akan digunakan sehingga peserta lebih mudah memahami materi kegiatan.

\section{HASILDAN PEMBAHASAN}

Hasil

Kegiatan sosialisasi dan pelatihan mengenai peningkatan pendapatan keluarga melalui teknologi internet online shop dan pendidikan anak di era digital ini dilaksanakan di Jalan Garuda Raya nomor 105 RT 02, RW 01, Kelurahan Beji Timur Kecamatan Beji Kota Depok dengan nara sumber para dosen dari Fakultas Ekonomi UNJ dan dibantu oleh tim panitia. Peserta pelatihan sebanyak 30 orang, terdiri dari ibu-ibu PKK, kelompok pengajian dan remaja karang taruna. Pelaksanaan kegiatan dilaksanakan di salah satu rumah tokoh masyarakat setempat yaitu Ibu Retno Wijayanti, S. Si Apt yang merupakan Ketua Forum Kota Layak Anak (FOKLA) Depok. Pelaksanaan sosialisasi dan pelatihan tersebut juga melibatkan kerjasama dengan Yayasan Tunas Ilmu dan FOKLA. Kerjasama dilakukan dalam bentuk bazaar, dimana para ibu-ibu rumah tangga menggelar barang jualan hasil karyanya diacara tersebut sehingga memotivasi peserta 
dalam menumbuhkan semangat berwirausahanya.

Keterlibatan ibu-ibu PKK, kelompok pengajian, dan remaja karang taruna dalam kegiatan tersebut diharapkan dapat menghasilkan motivasi berwirausaha, meningkatkan keterampilan dalam menggunakan internet untuk meningkatkan pendapatan keluarga, serta meningkatkan pemahaman terkait pendidikan anak di era digital.

Kegiatan yang dilaksanakan pada hari Selasa, 4 Oktober 2016 dari jam 09.00 sampai dengan 14.30 WIB diawali dengan pembukaan, sambutan dari pihak tokoh setempat yakni, ketua FOKLA Depok, selaku tuan rumah, Ibu wakil ketua PKK RT 02, tim pengabdian kepada masyarakat FE UNJ, yang diwakili oleh Ibu Dr.Nuryetty Zain, MM. Selanjutnya acara dilanjutkan dengan sosialisasi materi pertama, dengan tema Peningkatan Pendapatan Keluarga melalui Teknologi Internet Online Shop, yang di sampaiakan oleh Marsofiyati, S.Pd, M.Pd. Sesi ini ditekankan pada keberhasilan peserta dalam menyerap materi khususnya melalui sesi tanya jawab secara interaktif di antara para peserta juga nara sumber dengan memberikan door prize untuk memancing keaktifan peserta dalam kegiatan tersebut. Keberhasilan lainnya juga ditekankan pada kemampuan peserta mempraktekkan online shop dengan media internet facebook. Para peserta dipilih dengan syarat memiliki fasilitas smartphone, sementara untuk fasilitas wifi disediakan oleh ketua FOKLA Depok. Selain itu diadakan sesi sharing dimana beberapa peserta menceritakan pengalaman pribadi mereka dalam melakukan jual beli barang secara online. Kemudian ada sesi diskusi oleh peserta secara berkelompok setelah sebelumnya diberikan kasus terlebih dahulu melalui video yang ditayangkan oleh nara sumber, kemudian salah satu perwakilan dari kelompok mempresentasikan hasil diskusi, diakhiri masukan dan arahan dari nara sumber.

Sesi kedua yang bertemakan pendidikan anak di era digital disampaikan oleh Susan Febriantina, S.Pd., M.Pd. Sesi kedua ini merupakan lanjutan dari sesi pertama, dengan titik tekan keberhasilan peserta dalam memahami materi. Dalam sesi kedua ini 
juga dilaksanakan tanya jawab secara interaktif di antara para peserta juga nara sumber, serta sharing pengalaman peserta dalam mendidik anak di era digital.

\section{Pembahasan}

Pelaksanaan sosialisasi dan pelatihan bagi masyarakat ini tidak dapat tercapa jika tidak mendapat dukungan dari berbagai pihak. Ada kecenderungan yang menganggap bahwa materi sosialisasi hanya sebagai retorika belaka, namun pada kenyataannya tidak seperti demikian. Sehingga untuk mengantisipasi hal tersebut, tim kami membuat strategi penyelenggaraan. Strategi yang kami gunakan adalah dengan melakukan pendekatan kepada para peserta sebagai orang yang langsung berkaitan dengan permasalahan serta memberikan fakta dan contoh nyata. Agar materi dapat dipahami dengan baik maka kami memilih metode pemberian materi dilanjutkan sesi tanya jawab, sharing, pelatihan (workshop), sesi diskusi oleh peserta secara berkelompok, kemudian salah satu perwakilan dari kelompok mempresentasikan hasil diskusi.
Kegiatan ini terkait dengan instansi seperti Universitas Negeri Jakarta yang membiayai kegiatan Pengabdian Masyarakat yang dilaksanakan oleh dosen-dosen sebagai sebuah kewajiban atas Tri Dharma Perguruan Tinggi serta pemerintah setempat mulai dari tingkat RW, RT didukung oleh Forum Kota Layak Anak Depok dan Yayasan Tunas Ilmu.

\section{KESIMPULAN DAN SARAN}

\section{Kesimpulan}

Pemanfaatan teknologi internet melalui online shop saat ini dinilai merupakan salah satu cara alternatif yang cukup efektif bagi para ibu-ibu rumah tangga serta remaja untuk meningkatkan pendapatan keluarga. Hal ini dikarenakan aktifitas tersebut dapat dilakukan dari dalam rumah masingmasing serta tidak perlu memerlukan modal yang cukup besar sehingga tidak terlalu memberatkan mereka. Dengan sistem bisnis dari dalam rumah, ibu-ibu rumah tangga dan remaja selain dapat melakukan tugas utama mereka yakni mengurus keluarga, mereka juga dapat menghasilkan income yang bermanfaat untuk keluarga mereka. Dengan sistem 
sebagai reseller dan dropship mereka juga tidak diberatkan dengan ketersediaan barang yang tentunya memerlukan modal yang cukup besar serta ongkos kirim karena sistem pengiriman yang langsung dapat dilakukan dari agen ke konsumen.

Selain pemanfaatan internet untuk menambah pendapatan keluarga oleh ibu-ibu rumah tangga, peran ibu sebagai pendidik utama anak-anaknya semakin kuat karena dibekali dengan ilmu parenting. Pada kenyataannya keluarga di Indonesia khususnya wilayah kota Depok, yang merupakan sebuah urban area dan merupakan cyber city dengan tingkat perkembangan internet yang cukup pesat menuntut para ibu rumah tangga semakin peka, peduli dan tanggap terhadap perkembangan internet tersebut khususnya dalam mendidik dan mengawasi perkembangan anak-anaknya. Tidak sedikit kasus kekerasan seksual, penculikan anak, pornografi dikalangan anak-anak dan remaja di kota Depok yang disebabkan oleh penyalah gunaan internet. Hal tersebut juga berkaitan dengan kesalahan pola asuh orang tua dalam mendidik anak-anaknya, terutama di era digital saat ini.

Hasil yang dicapai dalam kegiatan ini adalah pertama peserta merasa puas dan senang terhadap kegiatan tersebut, terbukti dari data kehadiran, peserta tekun mengikuti kegiatan sampai selesai dengan jumlah tetap dan tidak berkurang. Kedua, peserta juga antusias dalam memberikan tanggapan dan pertanyaan kepada nara sumber yang memandu kegiatan tersebut. Ketiga, adanya kerjasama dengan pihak lain seperti FOKLA Depok dan Yayasan Tunas Ilmu yang turut berpartisipasi menyukseskan kegiatan tersebut. Sehingga, dapat kami simpulkan bahwa kegiatan ini sangat diminati peserta dan tentunya sangat memberikan manfaat bagi warga sekitar.

\section{Saran}

Dalam kegiatan ini beberapa saran yang dapat disampaikan adalah bahwa kegiatan ini sangat bermanfaat bagi masyarakat sekitar, khususnya di era yang serba canggih dengan pemanfaatan internet. Topik yang dipilih sangat tepat dan sesuai dengan kondisi nyata dilapangan, yakni kemunculan sebuah era baru (digital 
era) yang serba memanfaatkan internet dalam kehidupan sehari-hari, termasuk dalam hal meningkatkan pendapatan keluarga serta pendidikan anak telah menjadi sebuah keharusan, trend dan gaya hidup masyarakat Indonesia. Karenanya, diharapkan kegiatan ini dapat dilakukan secara berkelanjutan dengan jumlah dana yang dianggarkan dapat ditingkatkan.

\section{DAFTAR PUSTAKA}

Jogiyanto, H.M., (2006). Pengenalan Komputer. Yogyakarta: Andi Offset

Santrock, J. W. (2010). Educational psychology 9 (5ed). New York: McGraw-Hill

Shunk, D. H. (2012). Learning Theories, an educational perspective, Sixth Ed, Boston, MA: Person Education

Suryana. (2006). Kewirausahaan Pedoman Praktis: Kiat dan Proses Menuju Proses, Jakarta: Salemba 4.

Tilaar, HAR. (2002). Multikulturalisme; Tantangan-tantangan global \& masa depan dalam transformasi pendidikan nasional, Jakarta: PT Grasindo

Winardi, J. (2003). Entrepreneur dan Entrepreneurship.,

Jakarta: Kencana Prenada Media Grup

Williams, Brian K. (2007). Using Information Technology: Pengenalan Praktis dunia Komputer dan Komunikasi, Edisi 7, Yogyakarta: Andi

Available at

http://journal.unj.ac.id/unj/index.php/jpm
Zimmerer, Thomas W., Norman M. Scarborough. (2009).

Kewirausahaan dan Manajemen Usaha Kecil, Buku I, Jakarta: Salemba 4.

menggunakan
$\begin{aligned} & \text { Informasi, } \\ & \text { diterbitkan }\end{aligned}$

Pemkot Depok.(2015). Makalah Seminar Parenting. Menjadi Guru Pertama dan Utama Bagi Anak

Fokla. (2015). Modul Pelatihan Training of Trainers Parenting, Forum Parenting Kota Depok dan Forum Kota Layak Anak Kota Depok

http://www.kompasiana.com/atonimeto/ pentingnya-pendidikan-dalamkeluarga_54f68f92a333117d028b $510 \mathrm{~d}$.

http://tekno.kompas.com/read/2010/02/ 18/09054237/Fenomena.Indonesia di.Belantara.Trending.Topics.Twi tter

http://direkturbisnis.blogspot.co.id/2015 /12/ini-alasan-kenapa-anda-harusmemulai_27.html 